\title{
Modelling, Transient Response and Hydraulic Behaviour of 2DOF Stabilization Platform
}

\section{Ezz Eldin Ibrahim}

PhD. Student Military technical college Cairo.

Egypt

Tarek Elnady

Assistant Professor Military technical college Cairo.

Egypt

Mohamed Saffaa Hassan

Assistant Professor Military technical college

Cairo.

Ibrahim Saleh

Professor

Military technical college

Cairo.

Egypt

The main part of the hydraulic circuit of the hydraulic stabilization platform (HSP) is the electro-hydraulic servo valve (EHSV), which is very expensive due to its manufacturing requirements, so the proper selection for the geometrical configuration of electro hydraulic servo valve (EHSV) and maintaining the system stability are the main goal for estabilishing HSP. Also improving the performance of (HSP) to achieve the position tracking in two degrees of freedom (2DOF) based on modifying the different parameters of the hydraulic circuit (actuator size - hydraulic servo actuator geometric configuration-different load on the platform) to achieve the best performance. The system offers a proposal for an upper stabilized platform with moving lower base to be used with ships to achieve a stabilization condition for many purposes such as radar.

MATLAB Simulink and Simscape-multibody has been used in modeling the system. Changing the different parameters in the program block library input data (orifice area and spool slot width) to achieve best configuration of the system to be stabilized is discused.

The results show that using $0.6 \mathrm{~mm}^{2}$ servo valve orifice area and more raises the system pressure and has a bad effect on system stability, also using $4 \mathrm{~mm}$ servo valve slot width has more fluctuation in the system pressure in the transient time than using (3,2 or 1)mm slot width until approaching stable condition but has a better effect on system stability in the running (operation)time.

Keywords: servo valve, stabilization platform, electro hydraulic servo valve and stabilization platform.

\section{INTRODUCTION}

Stabilization platform (SP) has many applications in air, sea or ground. Examples for air applications are airborne camera stabilization (gimbal camera) which is mounted in the planes and is used for high Precession photo, the Hubble Scope Telescope used for space observation and the aircraft simulator used to simulate the motion of flight for pilot training purpose. Examples for sea applications are stabilization platform that is used in naval radar to stabilize the radar set while sailing and an unmanned ships which are used for military purpose that need a stabilized platform; also in ground applications it is used for tracking target in tanks.

Some platform applications deal with the error between the target that required to approach and the actual position that the platform reach, other platforms deal with the transient time that the platform take to approach the steady state condition and other deal with the maximum overshoot that is reached by the platform.

Most studies in this field deal with the control method used in the stabilization platform which is the input data to the (EHSV).

Received: April 2020, Accepted: August 2020

Correspondence to: Mr. Ezz Eldin Ibrahim

Military technical college,

Ismail Al Fangari, El-Qobba Bridge, Cairo, Egypt.

E-mail: ezzbos@gmail.com

doi:10.5937/fme2004833E

(C) Faculty of Mechanical Engineering, Belgrade. All rights reserved
This study is an attempt to assign a geometrical configuration for the electrohydraulic servo valve (EHSV) that helps to verify the required operation conditions for the stabilization platform.

Proportional valves are widely used in aerospace application instead of (EHSV), and hence a high response should be satisfactory, the time delay of the proportional valves is investigated by B. Xu. et al. [1], the valve composed of four subsystems which are mechanical, electronic, electromagnetic and fluid dynamics which are modeled in the study. The valve used in this study is pilot operated three-position four-port proportional directional valve, where the main spool is operated by the pilot pressure and its position is detected by the inductive position transducer (closed loop), the simulation study explained the reasons of the delay in four main regions.

The study focuses on the main delay parameters in the valve which are the electromagnetic force delay and the pilot valve dead zone. Tis study recommends to estigate how to diminish the delay caused by the previous two main parameters.

A modification in spool geometry of a proportion valve has been done experimentally and by simulation in Computational Fluid Dynamics (CFD) by E. Lisowski. et al. [2]. In order to reduce the flow force value, four proposed geometry modifications on the spool have been used which are single notch - no relief grooves, two symmetrical notches - no relief grooves, single 
notch with relief grooves and two symmetrical notches with relief grooves. The purpose of the grooves is to allow the fluid flow before main gaps are opened. The study deduced that the Reduction in motion resistance has been achieved using two notches arranged symmetrically on both sides of the spool, which resulted in significant radial force compensation.

Cavitation phenomenon in the flapper nozzle of pilot stage in servo valve has been investigated by many researches. In order to maintain the valve in an appropriate condition, modification of flapper shape has been studied by NayZar A. et al. [3]. Different flapper shape have been studied by simulation. A rectangular shape flapper achieved a reduction in cavitation compared with the traditional curved edge. The performance of the flow control is the same in both traditional and proposed structure of the flapper.

A new technique has been studied by He Yang et.al. [4], to reduce the cavitation phenomenon in the flapper of the pilot stage of the servo valve which is create a micro jet with the main jet. A simulation study is made by the aid of FLUENT 17.0. An experimental validation has been done to the mass flow rate measurements. The study concludes that using of the micro jet has a great contribution to the reduction of the cavitation on the flapper region even by applying a high pressure.

Most research dealt with the control of hydraulic simulator (manipulator) as an example of hydraulic stabilization platform. Some research studies use a pneumatic actuators others use hydraulic actuators. The trend in the research is to construct an algorithm which observe and control the disturbance or error of the system.

In 2008 HongBo et al [5] designed a cascade control of hydraulic (6DOF) platform. A mathematical model was obtained with mechanical and hydraulic dynamics, modeling of hydraulic servo actuator was obtained using the continuity equation and the equation of motion, and also a simple linearizing the relationship between the flow rate and the valve displacement and the pressure by defining a proportional constant between valve input voltage and valve displacement. The control of the system consists of inner and outer loop control by velocity and load feedback. It uses a cascade controller based on sliding mode and is experimentally compared with a well-tuned proportional controller.

In 2010 a disturbance observer of a six-degree of freedom (6DOF) manipulator was constructed by Yangjun Pi, [6] and then a cascade control was applied using cascade controller. A mathematical model is obtained for both kinematics and dynamics of actuators, which determine the length of the actuators during the motion of the platform (kinematics), and also continuity equation and equation of motion are used to determine the dynamics of the actuators. An inner loop controller was designed to detect the error between the actual force acting on the piston and the desired force. An outer loop was designed to define the desired force. The aim of this paper is to add a new algorithm which detects the disturbance force acting by fluid dynamics on the actuators and hence the error between the desired force and the actual force acting on the platform are well known to approach the stabilization state.

In 2013 Justin et al [7] developed a platform driven by seven pneumatic actuators (6) actuators like Stewart platform [8] with addition actuator in the middle). The usage of pneumatic actuators instead of hydraulic ones is to obtain a high dynamic motion with low power and hence low cost. Pneumatic actuators required a more complicated control compared with hydraulic due to the nonlinearities of the system. A mathematical model was obtained for both dynamic and kinematic of the cylinder by means of other research. The desired length of each actuator was obtained. Two controllers were used to approach the desired motion with respect to the experimental measurements (actual condition). [9-11].

The selection of 3DOF manipulator as an aplicaion of centrifuge for pilot training was discussed by Dančuo et al [12].

A proposal for manned mission to Mars is simulated by $\mathrm{G}$ load by Dančuo et al [13].

\section{SYSTEM DESCRIPTION}

The system used in fig(1) is composed of upper base (1), lower base (2), connected via two hydraulic actuators(3), by yoke joint(4), and mid cylinder (5) to prevent axial motion.

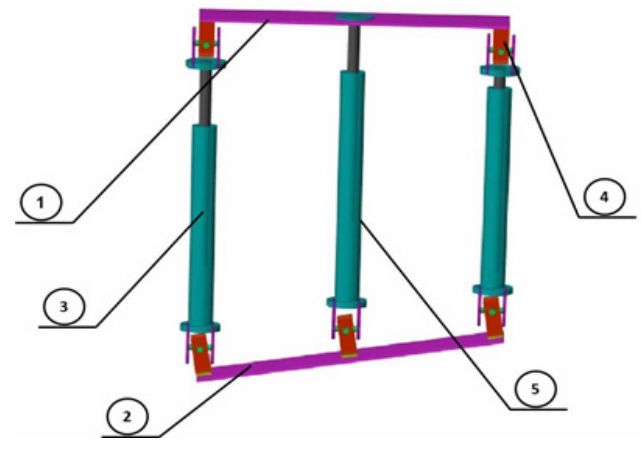

Figure 1. Two degree of freedom (2DOF) model demonstration.

Figure (2) demonestrates the block diagram of the overall control system which consists of input signal acted on the lower plate of the system and a feed back from this motion to the rotation matrix which convert the angular motion to a linear motion in the form of signal input to each of the actuator. Then a PID controller block to adjust this motion and reduce system error and deliver this signal to the two servo valve blocks to operate the two actuators in order to maintain the upper plate stabilized.

Figure (3) demonstrates the hydraulic circuit of the system which is composed of hydraulic pump (1), relief valve (2) that delivers the hydraulic to the flow devider (3) to divide and feed it to two one way valve (4), then to the two electro-hydraulic servo valve (5) that control the motion of the tow actuators (6).

The upper base is tried to be stabilized against motion from the lower base which is in two degree of freedom (z direction up and down - pitch around y axis). The input trajectory is assumed to be sinusoidal wave with amplitude $200 \mathrm{~mm}$ for $\mathrm{z}$ direction and 10 degree around y axis.

The length vector of the actuator to extract or retract depends on inversing the length vector resulting from converting the motion between tow plates. One is moving while the other is fixed as in parallel multi-manipulator Platform which is derived by Serdar Kucuk in 1999, [14]. It will be discussed in the following section. 


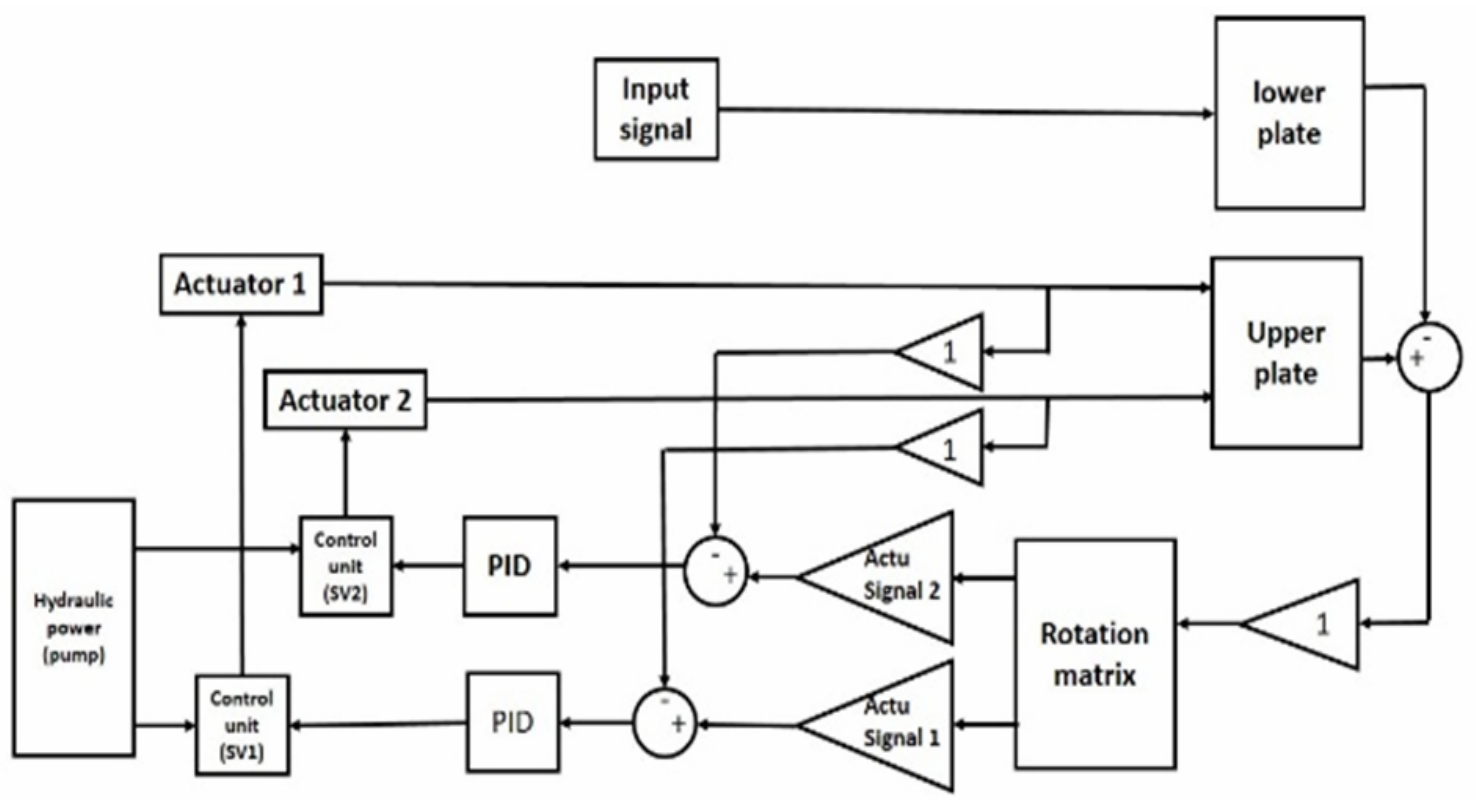

Figure 2. The block diagram of the control system

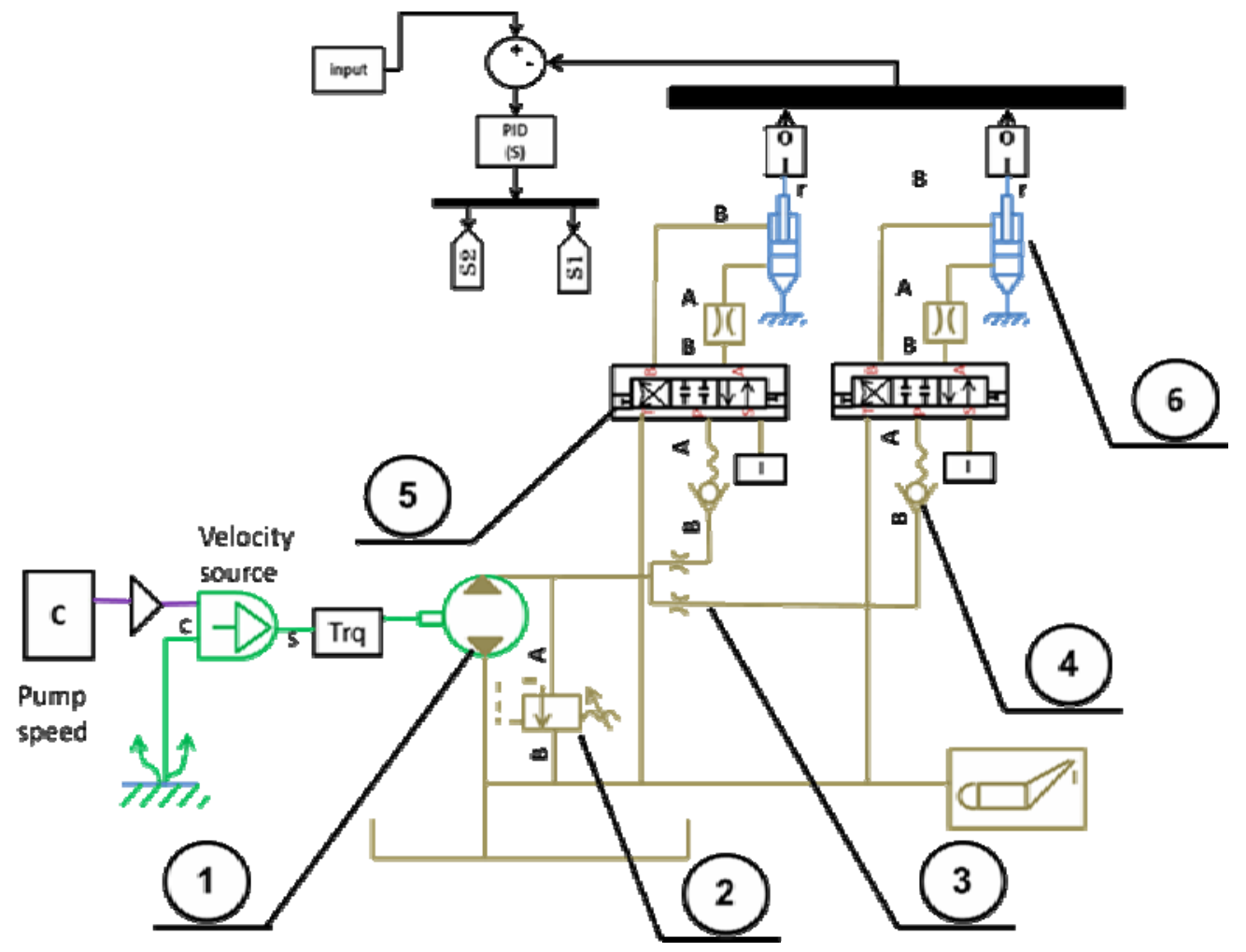

Figure 3. Two degree of freedom (2DOF) hydraulic circuit

\section{ANALYSIS FOR KINEMATICS}

In the commonly parallel multi-manipulator Platform 6 degrees-of-freedom, the motion is three linear translations in the $\mathrm{x}, \mathrm{y}$ and $\mathrm{z}$ direction and three rotations about the three axes $\psi, \theta$, which are yaw, pitch and roll respectively.

Fig (4) shows the two frames which are fixed and are moving.

The length vector between the fixed plate (reference frame) and moving plate (platform frame) $(l)$ is determined from the following equation,

$$
l=t+\mathrm{R} p-b
$$

where $l$ is the length vector of each actuator, $t$ is the translation vector of the moving platform frame with respect to the reference frame, $p$ is the position vector of each actuator with respect to the moving frame, $b$ is the position vector of each actuator with respect to the reference frame and $\mathrm{R}$ is the combined rotation matrix between fixed and moving frames by the given input rotation angles in yaw, pitch and roll $\psi, \theta, \quad$ as discussed in [5].

$$
\left[\begin{array}{ccc}
c \psi . c \theta & c \psi . s \theta . s \varphi-s \psi . c \varphi & s \psi . s \varphi+c \psi . s \theta . c \varphi \\
s \psi . c \theta & c \psi . c \varphi+s \psi . s \theta . s \varphi & s \psi . s \theta . c \varphi-c \psi . s \varphi \\
-s \theta & c \theta . s \varphi & c \theta . c \varphi
\end{array}\right]
$$


where $c \psi \ldots .$. is $\cos \psi$ and $\mathrm{s} \psi \ldots \ldots$ is $\sin \psi$ and etc.

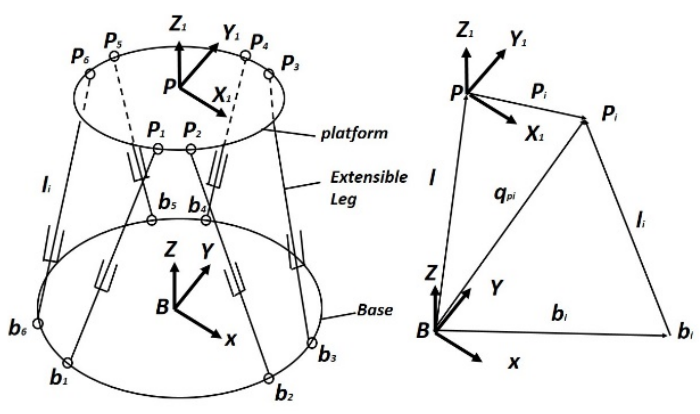

Figure 4. Six degree of freedom (6DOF) stabilization platform and its coordinates

This study deals with two degrees of freedom (2DOF), so the translation in both $\mathrm{x}$ and $\mathrm{y}$ direction will be neglected and the rotation around $x$ and $z(\psi \quad)$ will also be neglected. It means that only translation in $\mathrm{z}$ direction and rotation around $y$ axis (pitch) will be under research.

\section{ELECTROHYDRAULIC SERVO VALVE MATHE- MATICAL MODEL}

An electrohydraulic servo valve (EHSV) is a valve that is operated electrically to control the hydraulic fluid direction which operates the actuator. It is mainly used to control powerful the hydraulic actuators with a small electrical signal, and it can precisely control position, velocity, pressure, and force.

The servo valve mathematical model was derived in 2009, by G. Rabie, [15] shown in fig. (5). It consists of electromagnetic torque motor (1), which drive the flapper (2), that creates a pressure difference between the two nozzles (3), forces the spool (4), allows the pressure port (5), feeds either port (6) or (7), while the other side of the spool allows the hydraulic oil to return through the return port (8), while the two orifices (9) apply a pressure difference.

The torque motor shown in fig. (6) consists of Polar pieces (1), Permanent magnet (2), Flexible tube (3), Flapper (4), Control coils (5) and Armature (6).

The effective torque delivered by the electromagnetic motor is given by the following equation.

$$
T=\mathrm{K} i * i
$$

where

$$
K i=\frac{N \lambda \mathrm{p} \mu 0 \mathrm{AL}}{2 \mathrm{X}^{2}}
$$

$\& \mathrm{i}$ input current. N. number of turns of the coil, $\lambda \mathrm{p} .$. magneto-motive force of the permanent magnet, $\mu 0 \ldots$ permeability of free space, A... area of air gap. L.. armature length, $\mathrm{X}_{0}$.. length of the air gap in the neutral position of the armature.

The armature equation of motion is

$$
T=J \frac{\mathrm{d}^{2} \theta}{\mathrm{d} \mathrm{t}^{2}}+\mathrm{f} v \frac{\mathrm{d} \theta}{\mathrm{d} \mathrm{t}}+\mathrm{kt} \theta+T l+T p+T F
$$

where $J \ldots$ is the moment of inertia of the rotating parts, $\mathrm{T}_{l} \ldots$ is the torque due to flapper displacement limiter, $\mathrm{f}_{v}$. is the damping coefficient, $\mathrm{K}_{t}$. is the stiffness of flexure tube, $\mathrm{T}_{F}$. is the feedback torque, $\mathrm{T}_{p}$. is the torque due to the pressure forces.

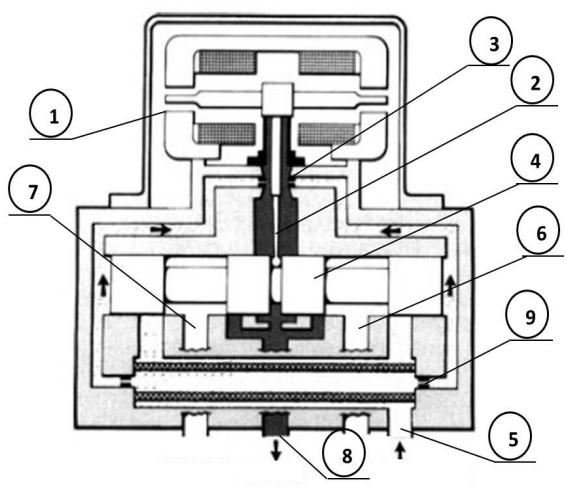

Figure 5. Two-stage servo-valve with mechanical feedback.

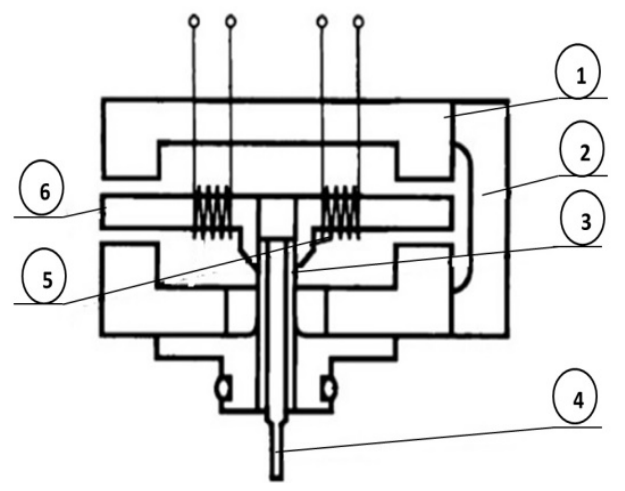

Figure 6. electro-magnetic torque motor.

The flow rate as shown in fig. (7), affecting on the flapper and make a pressure difference between both sides of the spool is obtained by

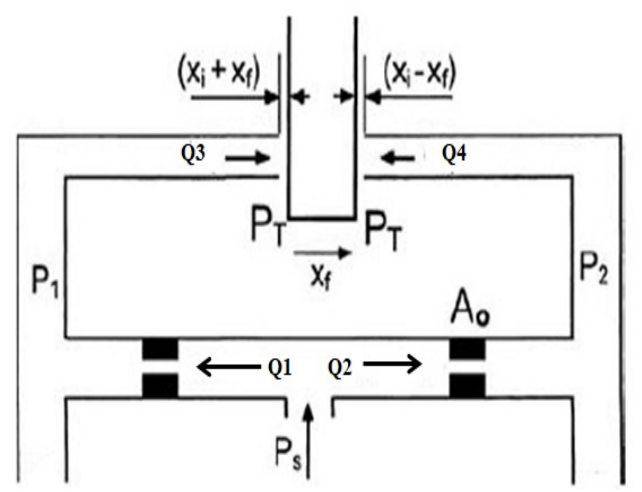

Figure 7. Schematic of a double jet flapper valve.

$$
\begin{aligned}
& \mathrm{Q} 1=C d A 0 \sqrt{\frac{2}{\rho}(P S-P 1)} \\
& \mathrm{Q} 2=C d A 0 \sqrt{\frac{2}{\rho}(P S-P 2)} \\
& \mathrm{Q} 3=C d \pi d f(X i+X f) \sqrt{\frac{2}{\rho}(P 1-P 3)} \\
& \mathrm{Q} 4=C d \pi d f(X i+X f) \sqrt{\frac{2}{\rho}(P 2-P 3)}
\end{aligned}
$$

where Q.. is the flow rate, $C_{d}$.. is the discharge coefficients, $\mathrm{A}_{0}$. is the orifice area, $\mathrm{d}_{f} .$. is the flapper 
nozzle diameter, Ps.. is the feeding pressure, $\mathrm{P}_{\mathrm{T}}$. is the return pressure, $\mathrm{X}_{f .}$. is the flapper displacement on the level of jet nozzles, $\mathrm{X}_{\mathrm{i}}$.. is the initial flapper nozzle opening, $\rho$. is the oil density.

The flapper chamber continuity equations are

$$
\begin{aligned}
& \mathrm{Q} 1-\mathrm{Q} 3+\mathrm{As} \frac{\mathrm{dx}}{\mathrm{dt}}=\frac{V 0-A S X}{B} \frac{d p 1}{d t} \\
& \mathrm{Q} 2-\mathrm{Q} 4-\mathrm{As} \frac{\mathrm{dx}}{\mathrm{dt}}=\frac{V 0+A S X}{B} \frac{d p 2}{d t} \\
& \mathrm{Q} 3+\mathrm{Q} 4=\frac{V 3}{B} \frac{d p 3}{d t}
\end{aligned}
$$

$A_{\mathrm{s}} \ldots$ is the spool cross-sectional area, B.. is the bulk modulus of oil, $\mathrm{V}_{\mathrm{o}}$.. is the initial volume of oil in the spool side chamber, $\mathrm{V}_{3}$.. is the volume of the flapper valve return chamber.

The spool equation of motion is

$$
A S(P 2-P 1)=m_{s} \frac{\mathrm{d}^{2} x}{\mathrm{~d} \mathrm{t}^{2}}+\mathrm{fs} \frac{\mathrm{d} x}{\mathrm{~d} \mathrm{t}}+F_{j}+F_{s}
$$

\section{RESULTS AND DISCUSSION}

The system is validated as shown in fig. (8), with an experimental data used in [16] and it has a good agreement with the experimental result, with input sinusoidal wave $0.03(\mathrm{~m})$ bias $0.05(\mathrm{~m})$, a frequency $0.1(\mathrm{HZ})$ and PID controller which is an important item for adjusting and resolving the system error. It controls the system by evaluating the feedback of the system and compensating the system error. The mathematical equation of the PID controller is presented by Åström et al [17].

$$
u(t)=K P e(t)+K i \int_{0}^{t} e(t) d(t)+K d \frac{d e(t)}{d t}
$$

where $u(\mathrm{t})$ is the controller output, $\mathrm{e}(\mathrm{t})$ is the system error, $\mathrm{K}_{P}, \mathrm{~K}_{i}$ and $\mathrm{K}_{d}$ are the controller constants where $\mathrm{K}_{P}(20) \mathrm{K}_{i}(1) \mathrm{K}_{d}(0.01)$.

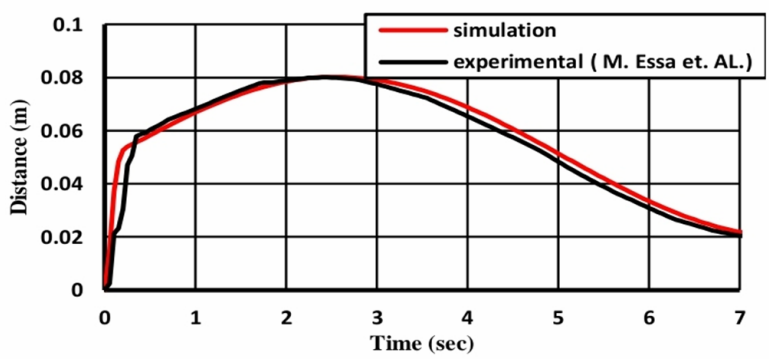

Figure 8. Experimental and simulation tracking

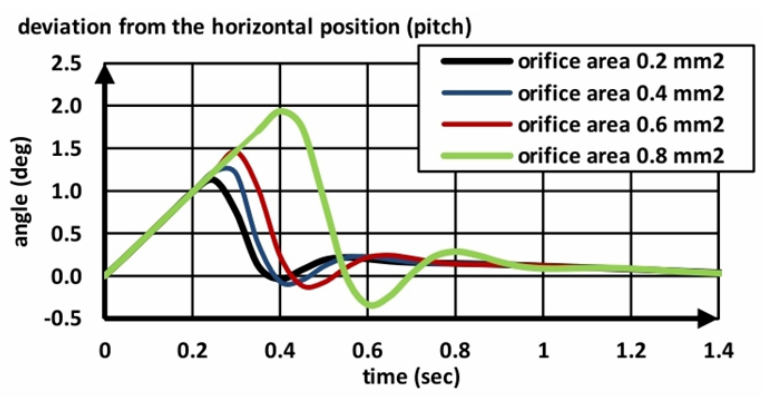

Figure 9. Effect of servovalve orifice area $(0.2,0.4,0.6$ and 0.8) $\mathrm{mm}^{2}$. on system stability
- $\quad$ The result in fig. (9) shows that using orifice area $\left(0.2 \mathrm{~mm}^{2}\right)$ the fluctuation in the transient time tells that reaching the steady state is less than any further more area, the platforms inclined (1.1 degree) in positive direction, and the system then fluctuated around (0 degree) (horizontal position) with a magnitude ( 0.2 degree) and transient time $(0.55 \mathrm{sec}$.).

- $\quad$ using orifice area $\left(0.4 \mathrm{~mm}^{2}\right)$ the platform made an overshoot more than using $\left(0.2 \mathrm{~mm}^{2}\right)$ orifice area in the transient time tells that reaching the steady state, the platforms inclined (1.2 degree) in positive direction, the system then fluctuated around (0 degree) (horizontal position) with a magnitude ( 0.2 degree), the transient time still $(0.55 \mathrm{sec}$.).

- using orifice area $\left(0.6 \mathrm{~mm}^{2}\right)$ the platform inclined tells that reaching the steady state, to record (1.5 degree) in positive direction, the system then fluctuated around ( 0 degree) (horizontal position) with a magnitude ( 0.2 degree) with transient time $(0.6 \mathrm{sec}$.).

- the clearly observed phenomena that if the orifice area increased to $\left(0.8 \mathrm{~mm}^{2}\right)$ the system start to fluctuate more and more and incline with relatively high inclination angle (1.9 degree) and also there is an increase in the transient time to $(0.75 \mathrm{sec}$. $)$.

- In fig. (10) and (11), using orifice area (0.2 $\mathrm{mm}^{2}$ ) reduces the pressure and hence reduce the consumed power by the system,

- $\quad$ using orifice area $\left(0.4 \mathrm{~mm}^{2}\right)$ consumed more pressure and hence more power is consumed by the system and the pressure .

- using orifice area $\left(0.6 \mathrm{~mm}^{2}\right)$ and more pressure consumed lead the system to the maximum pressure and hence open relief valve makes the system unstable in the transient time.

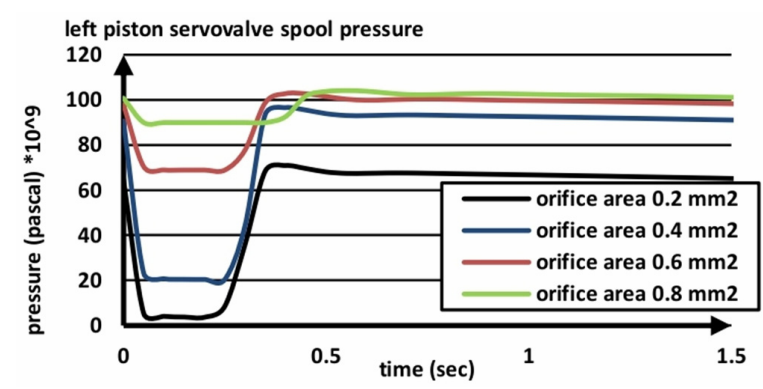

Figure 10. Effect of servovalve orifice area $(0.2,0.4,0.6$ and 0.8$) \mathrm{mm}^{2}$ on servovalve spool pressure (left side)

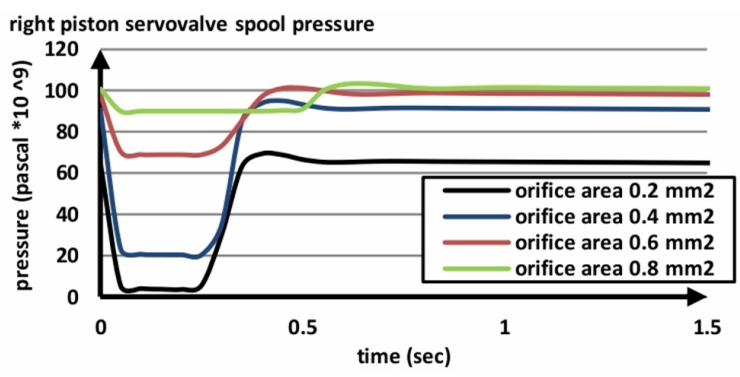

Figure 11. Effect of servovalve orifice area $(0.2,0.4,0.6$ and 0.8$) \mathrm{mm}^{2}$ on servovalve spool pressure (right side).

- The result in fig. (12) shows that the four used slot widths have different behaviour in the transient time, and also indicate that as the slot width increases the error during running time decreases. It means that the platform is inclined more by using small slot width. 
- using slot width (4 mm) made a relatively high fluctuation in the transient time, the system inclined 1.4 degree in positive direction to ( 0 degree) (horizontal position) and then is inclined 0.85 degree in negative direction to (0 degree). Then the system fluctuated around (0 degree) (horizontal position) with a magnitude (0.05 degree).

- $\quad$ using slot width $(2 \mathrm{~mm})$ made less fluctuation in the transient time, the system is inclined 1.2 degree in positive direction to ( 0 degree) (horizontal position) and then is inclined 0.5 degree in negative direction to $(0$ degree). Then the system fluctuated around (0 degree) (horizontal position) with a magnitude ( 0.1 degree).

- $\quad$ using slot width $(1 \mathrm{~mm})$ made less fluctuation than using $(2,3$ or $4 \mathrm{~mm})$ in the transient time but has more fluctuation in running (operation) time. The system fluctuated around ( 0 degree) (horizontal position) with a magnitude (0.2 degree), which means that the error of the system is increased during running conditions.

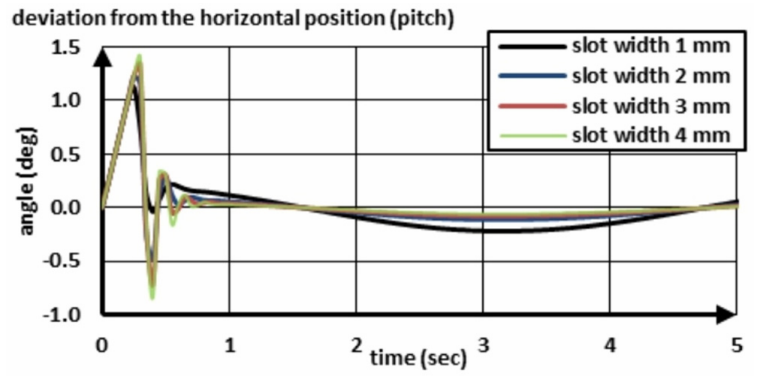

Figure 12. Effect of servovalve slot width (1, 2, 3 and 4) $\mathrm{mm}$. on system stability.

- $\quad$ in fig. (13) and (14), using slot width (1 mm) reduces the pressure fluctuation in the transient time and hence it explains the reason for the stability of the system in the transient time.

- the result shows that using $(2 \mathrm{~mm})$ slot width has more fluctuation in pressure than using $(1 \mathrm{~mm})$ slot width. Also as slot width increased the system pressure fluctuated more and more, which explains the reason for system instability in the transient time.

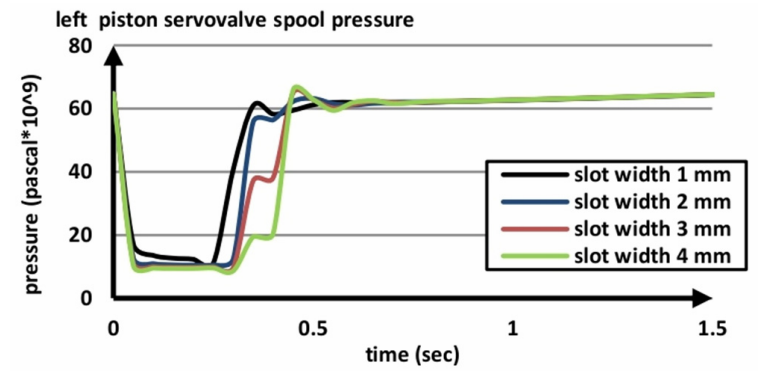

Figure 13. Effect of servovalve slot width (1, 2, 3 and 4) $\mathrm{mm}$. on servovalve spool pressure (left side).

right piston servovalve spool

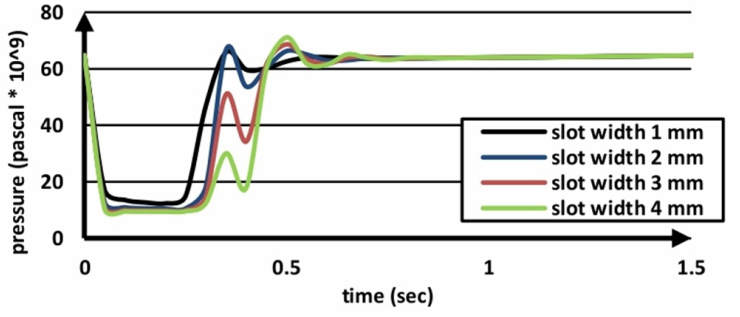

Figure 14. Effect of servovalve slot width (1, 2, 3 and 4) $\mathrm{mm}$. on servovalve spool pressure (right side).

\section{CONCLUSION}

Using $0.2 \mathrm{~mm}^{2}$ servo valve orifice area reduces the consumed pressure and there is hence less power consumption. It has a good effect on system stability on the transient time, while using $(0.4,0.6$ or 0.8$) \mathrm{mm}^{2}$ servo valve nozzle area consumed more pressure and has a bad effect on system stability.

Changing the orifice area doesn't affect the system error during running (operation) condition.

Using $4 \mathrm{~mm}$ servo valve slot width increases the fluctuation in pressure in the transient time and hence instability in transient time until approaching stable condition. But it has a good effect on system stability on running (operation) time, while using $(3,2) \mathrm{mm}$ servo valve slot width has less fluctuation in pressure in the transient time than using $4 \mathrm{~mm}$ slot width until approaching stable condition, which has relatively the same effect on system stability as $4 \mathrm{~mm}$ slot width.

Using $1 \mathrm{~mm}$ servo valve slot width has a low fluctuation in pressure in the transient time than using (2, 3 or 4$) \mathrm{mm}$ orifice width until approaching stable condition but it has a bad effect on system stability in the running (operation) time.

\section{NOMENCLATURE}

SP stabilization platform

HSP stabilization platform

EHSV electro-hydraulic servo valve

DOF degree of freedom

CFD computational fluid dynamics.

$\psi, \theta, \quad$ yaw, pitch and roll, respectively

$l \quad$ length vector of each actuator.

$t$ translation vector of the moving platform frame with respect to the reference frame

$p \quad$ position vector of each actuator with respect to the moving frame

$b \quad$ position vector of each actuator with respect to the reference frame

$R \quad$ combined rotation matrix

$C \psi, s \psi \quad \cos \psi$ and $\sin \psi$

$T \quad$ torque delivered by the electromagnetic motor

i input current

$\mathrm{N} \quad$ number of coil turns

$\lambda_{\mathrm{p}} \quad$ magneto-motive force of the permanent magnet

$\mu_{0} \quad$ permeability of free space.

A area of air gap

$\mathrm{L} \quad$ armature legnth

$\mathrm{X}_{0} \quad$ length of the air gap

$J \quad$ Moment of inertia of the rotating parts

$\mathrm{T}_{l} \quad$ torque due to flapper displacement limiter

$\mathrm{f}_{\mathrm{v}} \quad$ damping coefficient

$\mathrm{K}_{t} \quad$ stiffness of flexure tube

$\mathrm{T}_{F} \quad$ feedback torque

$\mathrm{T}_{\mathrm{p}} \quad$ torque due to the pressure forces

$\mathrm{Q} \quad$ flow rate

$\mathrm{C}_{\mathrm{d}} \quad$ discharge coefficient

$\mathrm{A}_{0} \quad$ orifice area

$\mathrm{d}_{\mathrm{f}} \quad$ Flapper nozzle diameter

$\mathrm{P}_{\mathrm{s}} \quad$ feeding pressure 
$\mathrm{P}_{\mathrm{T}} \quad$ returns pressure

$\mathrm{X}_{\mathrm{f}} \quad$ flapper displacement

$\mathrm{X}_{\mathrm{i}} \quad$ initial flapper nozzle opening

$\mathrm{P} \quad$ oil density

$\mathrm{A}_{\mathrm{s}} \quad$ spool cross-sectional area

B bulk modulus

$\mathrm{V}_{0} \quad$ initial volume of oil in the spool side

$\mathrm{V}_{3} \quad$ volume of the flapper valve return chamber

L actuator stroke

$\mathrm{V}_{\mathrm{g}} \quad$ geometric volume

$\eta_{\mathrm{v}} \quad$ volumetric eficiency

$\mathrm{D}_{\mathrm{n}} \quad$ nozzle diameter

m spool mass

$\mathrm{D}_{0} \quad$ orifice diameter

$\mathrm{K}_{p} \quad$ proportional coefficient

$\mathrm{K}_{i} \quad$ integral coefficient

$\mathrm{K}_{d} \quad$ derivative coefficient

\section{REFERENCES}

[1] J. Zhang, D. Wang, B. Xu, Z. Lu, M. Gan and Q. $\mathrm{Su}$, "Modeling and Experimental Validation of the Time Delay in a Pilot Operated Proportional Directional Valve," in IEEE Access, vol. 6, pp. 30355-30369, 2018, doi: 10.1109/ACCESS.2018. 2844164 .

[2] Lisowski, Edward, Grzegorz Filo, and Janusz Rajda. "Analysis of flow forces in the initial phase of throttle gap opening in a proportional control valve." Flow Measurement and Instrumentation 59 (2018): 157-167, doi.org/10.1016/j.flowmeasinst. 2017.12.011.

[3] Aung, Nay Zar, and Songjing Li. "A numerical study of cavitation phenomenon in a flappernozzle pilot stage of an electrohydraulic servovalve with an innovative flapper shape." Energy conversion and management 77 (2014): 31-39, doi.org/10.1016/j.enconman.2013.09.009.

[4] Yang, He, et al. "Cavitation reduction of a flappernozzle pilot valve using continuous microjets" International Journal of Heat and Mass Transfer 133 (2019): 1099-1109. doi.org/10.1016/j.ijhe atmasstransfer.2019.01.008.

[5] Guo, HongBo, et al. "Cascade control of a hydraulically driven 6-DOF parallel robot manipulator based on a sliding mode." Control Engineering Practice 16.9 (2008): 1055-1068, doi. org/10.1016/j.conengprac.2007.11.005.

[6] Pi, Yangjun, and Xuanyin Wang. "Observer-based cascade control of a 6-DOF parallel hydraulic manipulator in joint space coordinate." Mechatronics 20.6 (2010): 648-655, doi.org/10.016/ j.mec hatronics.2010.07.002 .

[7] J. Pradipta, M. Klünder, M. Weickgenannt and O. Sawodny, "Development of a pneumatically driven flight simulator Stewart platform using motion and force control," 2013 IEEE/ASME International Conference on Advanced Intelligent Mechatronics, Wollongong, NSW, 2013, pp. 158163, doi: 10.1109/AIM.2013.6584085.

[8] Stewart, Doug. "A platform with six degrees of freedom." Proceedings of the institution of mechanical engineers 180.1 (1965): 371-386, doi.org/10.1243/PIME_PROC_1965_180_029_02.

[9] Tran N.H., Tao Q.B., Huynh T.T., Tran X.T., Vo N.T. (2018) Modeling of Position Control for Hydraulic Cylinder Using Servo Valve. In: Nguyen N., Hoang D., Hong TP., Pham H., Trawiński B. (eds) Intelligent Information and Database Systems. ACIIDS 2018. Lecture Notes in Computer Science, vol 10752. Springer, Cham, doi.org/10.1007/978-3-319-75420-8_65.

[10]Fadel, M. Z., M. G. Rabie, and A. M. Youssef. "Motion control of an aircraft electro-hydraulic servo actuator." IOP Conference Series: Materials Science and Engineering. Vol. 610. No. 1. IOP Publishing, 2019, doi. org/article/10.1088/17578 99X/610/1/012073.

[11]Fadel, M. Z., M. G. Rabie, and A. M. Youssef. "Investigation of the operation of an electrohydraulic control system of a flying vehicle under failure conditions." The International Conference on Applied Mechanics and Mechanical Engineering. Vol. 18. No. 18th International Conference on Applied Mechanics and Mechanical Engineering.. Military Technical College, 2018.

[12] Dančuo, Z., Rašuo, B., Kvrgić, V., \& Zeljković, V. [2012]. Methodology of the main drive selection for a human centrifuge. FME Transactions, 40(2), 69-74.

[13]Dančuo, Z. Z., Rašuo, B. P., Bengin, A. Č., \& Zeljković, V. I. [2018]. Flight to Mars: Envelope simulation in a ground based high-performance human centrifuge. FME Transactions, 46(1), 1-9.

[14]Küçük, Serdar, ed. Serial and Parallel Robot Manipulators: Kinematics, Dynamics, Control and Optimization. BoD-Books on Demand, 2012.

[15] Rabie M.G. 2009 Fluid power engineering (New York, NY, USA: McGraw-Hill) 28

[16] M. E. M. Essa, M. A. S. Aboelela, M. A. Moustafa Hassan and S. M. Abdrabbo, "Control of Hardware Implementation of Hydraulic Servo Application Based on Adaptive Neuro Fuzzy Inference System," 2018 14th International Computer Engineering Conference (ICENCO), Cairo, Egypt, 2018, pp. 168-173, doi: 10.1109/ICENCO.2018.8636112.

[17] Åström, K.J., Hägglund, T.: PID controllers: theory, design, and tuning. Vol. 2. Research Triangle Park, NC: Instrument society of America, 1995.

\section{МОДЕЛИРАЊЕ, ОДЗИВ У ВРЕМЕНУ ПРЕЛАЗНОГ РЕЖИМА И ХИДРАУЛИЧНО ПОНАШАЊЕ СТАБИЛИЗАЦИОНЕ ПЛАТФОРМЕ ОД ДВА СТЕПЕНА СЛОБОДЕ}

\section{Е.Е. Ибрахим, Т. Елнади, М.С. Хасан, И. Салех}

Главни део хидрауличног кола хидрауличне стабилизационе платформе (ХСП) је електрохидраулични серво вентил (ЕХCВ) чија је 
производња веома скупа, па је адекватан избор геометријске конфигурације ХСП и одржавање стабилности система главни циљ успостављања платформе. Побољшање перформанси ХСП-а, у циљу праћења положаја код 2 степена слободе, се врши модификацијом различитих параметара хидрауличног кола (димензије актуатора геометријска конфигурација хидрауличног серво актуатора - различита оптерећења на платформи). У раду се даје предлог за стабилизовану горњу платформу са покретном доњом основом, која се може користити за постизање стабилизације бродова при коришћење радара и за многе друге намене.
Систем је моделиран коришћењем програма MATLAB Simulink и Simscape-multibody. Разматра се мењање различитих параметара за улазне податке блок библиотеке програма (зона отвора и ширина прореза калема) да би се постигла најбоља конфигурација система који треба стабилизовати.

Резултати показују да серво вентил са површином зоне отвора од $0,6 \mathrm{~mm}^{2}$ и навише подиже притисак у систему и да има негативан утицај на његову стабилност. При коришћењу серво вентила са ширином прореза од 4 мм јавља се већа флуктуација притиска у времену прелазног режима него када је ширина прореза 3, 2 или 1 мм све док се не достигне стабилност система у радном времену. 